Revista Eletrônica Geografar, Curitiba, v. 2, Resumos do VI Seminário Interno de Pós-Graduação em Geografia, p. 01-01. Junho/2007

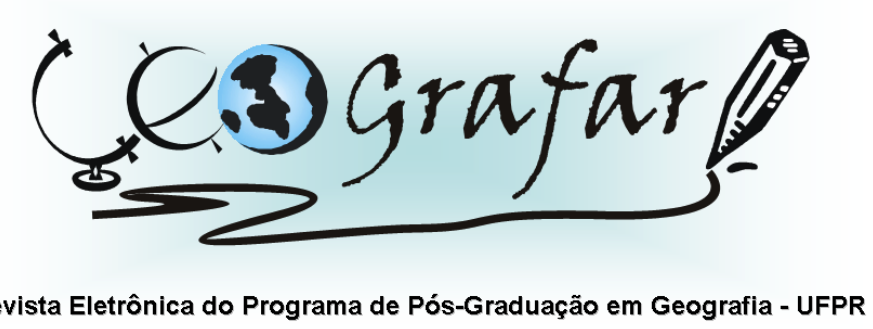

\title{
RECURSOS NATURAIS E COMUNIDADES TRADICIONAIS NO LITORAL DO PARANÁ: USOS E CONFLITOS
}

\section{ADRIANO CÉSAR BUZZATO ${ }^{1}$}

O bioma Mata Atlântica possui menos de $8 \%$ das formações originais. Exercendo influência direta em mais de $80 \%$ da população brasileira que vive em seu domínio, a conservação desse bioma é um verdadeiro desafio às gerações atuais. Emerge dessa forma a necessidade da criação de mecanismos de conservação mais eficientes e participativos, que visem ampliar a cobertura com espécies nativas. A área escolhida para o estudo de caso foi a Serra da Prata, no litoral sul do Estado do Paraná. Duas unidades de conservação (UCs) recobrem o domínio dessa Serra: a Área de Proteção Ambiental de Guaratuba e o Parque Nacional Saint-Hilaire/Lange. Por possuírem caráter restritivo, essas UCs geram conflitos com as comunidades que vivem dentro e/ou no entorno delas. O objetivo da pesquisa foi conhecer os impactos das populações humanas locais sobre os recursos naturais das UCs. Para compreender os potenciais conflitos de uso dos recursos que vêm ocorrendo na área foi necessária intensa pesquisa bibliográfica e visitas às comunidades. Os conflitos mais aparentes diagnosticados são: a extração de recursos da flora e da fauna e o uso dos recursos abióticos como o solo e a água, sem planejamento ou orientação profissional.

Palavras-chave: Recursos Naturais, Unidades de Conservação, Comunidades Tradicionais.

${ }^{1}$ Mestrando em Geografia - UFPR - email: buzzato@ufpr.br

Orientadora: ANA MARIA MURATORI 